\title{
CAUSES OF CONTRACTORS' CLAIMS IN INTERNATIONAL ENGINEERING-PROCUREMENT-CONSTRUCTION PROJECTS
}

\author{
Wenxin SHEN ${ }^{\mathrm{a}}$, Wenzhe TANG ${ }^{\mathrm{a}}$, Wenyang YU, Colin F. DUFFIELD ${ }^{\mathrm{b}}$, \\ Felix Kin Peng HUI ${ }^{\mathrm{b}}$, Yongping $\mathrm{WEI}^{\mathrm{c}}$, Jun FANG ${ }^{\mathrm{d}}$ \\ ${ }^{a}$ Tsinghua University, Institute of Project Management and Construction Technology, State Key Laboratory of \\ Hydroscience and Engineering, New Hydraulic Building, Beijing 100084, China \\ ${ }^{b}$ Dept. of Infrastructure Engineering, The University of Melbourne, Victoria 3010, Australia \\ ${ }^{c}$ School of Geography, Planning and Environmental Management, The University of Queensland, Australia \\ ${ }^{d}$ Sinohydro Bureau 7 Co., LTD, Chengdu 610081, China
}

Received 18 Jun 2016; accepted 03 Oct 2016

\begin{abstract}
Engineering-Procurement-Construction (EPC) method has increasingly been applied in international markets. In this research, the causes of contractors' claims in international EPC projects are modeled and empirically tested with industry survey, structural equation modeling and case studies from the perspective of Chinese contractors. The established model outlines the causes of contractors' claims as: external risk (sociopolitical risks, economic risks, and natural hazards), clients' organizational behavior (untimely payment, change orders, and inefficient processing), and project definition in contract (unclear scope of works, and unclear technical specification). The structural equation modelling validates that these causes have direct influences on claim respectively. Besides, clients' organizational behavior acts as a partial mediation between external risk and claim, demonstrating that external risk can also exert influence on claim through affecting clients' organizational behavior. Seven case studies further confirmed and interpreted the substantive meaning of these relationships. This study establishes interdisciplinary linkages among knowledge areas of contracting, risk management, organizational behavior, and international EPC project delivery, which has important primary contributions in both theory and practice. Understanding how the fundamental factors interactively lead to claims can help contracting parties to develop effective claim strategies, proactively mitigate project risks, and ultimately improve EPC project performance.
\end{abstract}

Keywords: claims, EPC, risk management, organizational behavior, project definition, international project, Chinese contractors.

\section{Introduction}

EPC method has increasingly gained acceptance in international markets (Guo et al. 2010). As a fast-track project delivery strategy, EPC method can lever a contractor to fulfill the design, procurement, and construction tasks simultaneously in achieving early builder involvement, cost savings, and reduced duration (Hale et al. 2009). Nevertheless, compared to the traditional method of Design-Bid-Build (DBB), more uncertainties are left in EPC approach, which may make EPC projects risky, especially for contractors (Öztaş, Ökmen 2004). Allocating the occurred risks between the client and the contractor in the construction process largely involve claims (LaBarre, El-adaway 2013). It is agreed that as an indispensable part of contract systems, claims have negative impacts on projects and become an inevitable burdens to the construction industry (El-adaway, Kandil 2009; Ho, Liu 2004; Vidogah, Ndekugri 1998). Management of claims is one of the biggest challenges in current changing international construction industry (Kululanga et al. 2001).

In EPC projects, the signed contracts are normally based on conceptual design, leaving many clients' requirements being not clearly elaborated (Öztaş, Ökmen 2004). As the projects proceed, clients may give rise to change orders, which could lead to contractors' claims related to variations (Abdul-Malak et al. 2002). Besides, external risks arising from complex international sociopolitical and natural environments (such as war, terrorism, strike and natural catastrophes) may also result in claims as regulated by EPC contract form (FIDIC 1999). From perspective of integration management, EPC approach may mitigate the potential for claims, since designers and suppliers are the team members of contractors, which could largely reduce the claims related to errors, omissions, and miscommunication (Pishdad-Bozorgi, Garza

Corresponding author: Wenzhe Tan

E-mail:twz@mail.tsinghua.edu.cn 
2012). Therefore, EPC approach could either increase or decrease the probabilities of contractors' claims in international project delivery, and there is a clear need to study this complex issue to learn how various factors could actually influence contractors' claims in international EPC projects.

Existing studies have identified wide-range causes of claims, which are related to industrial, financial, social, political, organizational behavior, contractual, environmental, and project-related factors (Cheung, Pang 2013; Fawzy, El-adaway 2012; Love et al. 2011; Abd El-Razek et al. 2008; Sambasivan, Soon 2007; Yates, Epstein 2006; Harmon 2003; Odeh, Battaineh 2002). However, little research has systematically addressed and quantified the relationships among the above factors and their association with claims in international EPC projects. Cause-effect analysis is a systematic approach to find the basic reason for undesirable consequences, which assists in preventing the recurrence of the contractual problems (Rosenfeld 2014). Owing to that the causes of claims are complexly interrelated with a variety of factors (Chau 2007), understanding the in-depth mechanism on causes of claims can help project parties to appropriately choose contracting strategies, proactively mitigate project risks, and ultimately improve project performance. Thus, the aim of this study is to quantitatively investigate how the above factors interactively lead to contractors' claims by developing and testing a model, with support of the data collected from the experienced Chinese contractors in delivery of international EPC projects.

\section{Conceptual model on causes of contractors' claims in EPC projects}

\subsection{Development of the conceptual model}

Many studies have identified the main causes of claims in project delivery from the viewpoints of different pro- ject participants. The contributing factors to contractors' claims from previous research can be categorized into six factors: 1) external risk (e.g., events that project parties could not control); 2) client related factor (e.g., change orders); 3) consultant related factor (e.g., delay in inspection and approval); 4) designer factor (e.g., design errors and omissions); 5) supplier related factor (e.g., problems on materials and equipment); 6) project definition in contact (e.g., unclear scope of work and ambiguous technical requirement) (LaBarre, El-adaway 2013; Mahamid et al. 2012; Abd El-Razek et al. 2008; Sambasivan, Soon 2007; Odeh, Battaineh 2002; Semple et al. 1994).

From perspective of EPC contractors, claims resulting from designer and supplier related factors could not be raised against the client since the designer, the supplier and the constructor are working as one team (PishdadBozorgi, Garza 2012). Thus, designer and supplier related factors should be excluded from the causes of contractors' claims in EPC projects. Both client and consultant related factors could be considered as clients' organizational behavior, as consultants act as agents for clients in conveying clients' orders to contractors and making relevant decisions such as approving the contractor's design option (Tang et al. 2009). Therefore, on the basis of the above identified six factors, the causes of contractors' claims in EPC projects could be refined as three factors: 1) external risk, 2) clients' organizational behavior, and 3) project definition in contact. The key indicators of these factors are summarized and listed in Table 1.

These three factors could either independently or interactively result in contractual problems (Williamson 1979; Mitropoulos, Howell 2001), leading to contractors' claims in delivery of international EPC projects. Accordingly, a conceptual model on causes of contractors' claims in EPC projects is established to help understand the relationships among external risk, clients' organizational behavior, project definition in contract, and claim,

Table 1. Key indicators of the causing factors on contractors' claims in EPC projects

\begin{tabular}{|c|c|c|}
\hline Factors & Indicators & References \\
\hline \multirow[t]{3}{*}{ External risk } & Sociopolitical risks & $\begin{array}{l}\text { Cheung and Pang (2013); Mahamid et al. (2012); Hanna 2007; } \\
\text { Mitropoulos and Howell (2001); Molenaar et al. (2000); FIDIC (1999) }\end{array}$ \\
\hline & Natural hazards & $\begin{array}{l}\text { Cheung and Pang (2013); Assaf and Al-Hejji (2006); Harmon (2003); } \\
\text { Mitropoulos and Howell (2001); FIDIC (1999); Semple et al. (1994) }\end{array}$ \\
\hline & Economic risks & $\begin{array}{l}\text { Cheung and Pang (2013); Hanna (2007); Harmon (2003); Mitropoulos } \\
\text { and Howell (2001); FIDIC (1999) }\end{array}$ \\
\hline \multirow[t]{3}{*}{$\begin{array}{l}\text { Clients' organizational } \\
\text { behavior }\end{array}$} & Untimely payment & $\begin{array}{l}\text { Mahamid et al. (2012); Assaf and Al-Hejji (2006); Kululanga et al. } \\
\text { (2001); FIDIC (1999) }\end{array}$ \\
\hline & Change orders & $\begin{array}{l}\text { Mohamed et al. (2011); Assaf and Al-Hejji (2006); Kululanga et al. } \\
\text { (2001); FIDIC (1999) }\end{array}$ \\
\hline & Inefficient processing & $\begin{array}{l}\text { Cheung and Pang (2013); Mahamid et al. (2012); Mohamed et al. } \\
\text { (2011); Kululanga et al. (2001); FIDIC (1999); Semple et al. (1994) }\end{array}$ \\
\hline \multirow[t]{2}{*}{$\begin{array}{l}\text { Project definition } \\
\text { in contract }\end{array}$} & $\begin{array}{l}\text { Unclear technical } \\
\text { specification }\end{array}$ & $\begin{array}{l}\text { Cheung and Pang (2013); Hanna (2007); Mitropoulos and Howell } \\
\text { (2001); Kululanga et al. (2001); Molenaar et al. (2000) }\end{array}$ \\
\hline & Unclear scope of works & $\begin{array}{l}\text { Pishdad-Bozorgi and Garza (2012); Mohamed et al. (2011); Hanna } \\
\text { (2007); Harmon (2003); Molenaar et al. (2000); Levin (1998); Semple } \\
\text { et al. (1994) }\end{array}$ \\
\hline
\end{tabular}




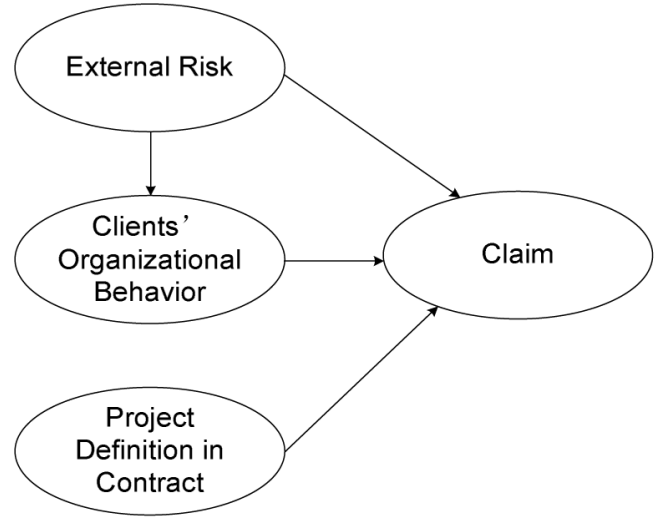

Fig. 1. Conceptual model on causes of contractors' claims in EPC projects

which presents the relationships underpinned by four hypotheses, as shown in Figure 1.

\subsection{H1: External risks have an influence on claim}

Due to diverse uncertainties from complex external environment, undertaking international projects is much riskier than domestic projects (Gunhan, Arditi 2005). External risks are the uncontrollable factors that relate to global/ local markets, sociopolitical conditions, and natural environment, which may have significant impacts on projects (Zhi 1995). During long-term delivery of international EPC projects, high level of external risks (including economic risks, sociopolitical risks, and natural hazards) may result in delays and losses, which could generate claim (Akintoye, Macleod 1997; Ren et al. 2001). Economic risks can be attributed to changes in interest rates, currency exchange rates, tax/duty rates, labor force prices, materials/equipment prices, and financing conditions (Iyer, Sagheer 2010). Sociopolitical risks could result from war, military action, terrorism, riot, strike, embargo, change in law, government intervention, and change of regime (Chan et al. 2010). Natural hazards include earthquake, hurricane, typhoon, flood, landslide, and mudflow (Tang et al. 2013; El-Adaway, Kandil 2010). These external risks, which may be unforeseeable at the outset, are notable claim sources in international EPC project delivery (Tang et al. 2007).

\subsection{H2: Clients' organizational behavior have an influence on claim}

As an EPC contractor is responsible for design/procurement/construction as a single entity, the key difference between EPC and DBB contract strategy lies in that risk allocation of various events is more concentrated in clients and contractors, and claims in EPC projects are mainly involved with the organizational behaviors of these two parties (Galloway 2009). Contractors may submit claims that are attributed to clients' organizational behaviors such as delay in payment, change orders and inefficient processing (Chester, Hendrickson 2005), but clients may reject the claims for the reasons of inaccurate estimation, insufficient supporting documents, and contractors' opportunism behaviors (Cheung, Pang 2013; Levin 1998; Williamson 1979). Thus, clients' organizational behavior during construction process is an important source of claims, which should be a management emphasis in EPC project delivery (Mitropoulos, Howell 2001).

\subsection{H3: Project definition in contract has an influence on claim}

Project definition in EPC contracts, prepared on the basis of conceptual design, normally has left many internal uncertainties due to some requirement being unable to elaborate at the early stage (Love et al. 2011). Nevertheless, clients are required to provide proper project definitions on the requirements of project objectives, critical issues, programs and functions (Xia et al. 2013; Chan, Tse 2003). Without clear definitions of work scope and technical specification, it could be difficult for the client and the contractor to reach agreement on whether project performances have met the requirements (Chan et al. 2005). Therefore, unclear project definitions, which are related to the technical nature of EPC method, can also be an important cause of claims and disputes (Ren et al. 2001).

\subsection{H4: External risks have an influence on client's organizational behavior}

External risks arising from complex international environment can not only directly cause claims, but also have major impact on project participants' organizational behaviors (Mitropoulos, Howell 2001). Most organizational decisions and actions can be sourced from stimuli in the uncertainties of external environment (Daft 2010). Global financial crisis can lead to clients' difficulty in financing, which may result in the delay in payments to contractors (Iyer, Sagheer 2010). Untimely payments by clients can affect the cash flow of contractors in processing project activities, which is a source of claims (Akintoye, Macleod 1997). Sociopolitical risks can result in clients' delay in approval, slowness in decision making, untimely delivery of sites to contractors, and suspension of work, which can also trigger claims (Assaf, Al-Hejji 2006). Natural hazards such as earthquake, extreme weather, and flood can lead to heavy losses and significant delays, and relevant disputes may arise from assessing and quantifying the overall loss and delayed time (Orabi et al. 2009).

\subsection{Empirical research questions}

Based on the foregoing sections, contractors' claims in EPC projects are influenced directly by external risk, clients' organizational behavior, and project definition in contract; besides, external risk can also affect clients' organizational behavior. As shown in Figure 1, the arrows in the conceptual model represent the directions of the hypothesized relationships. 
To test the conceptual model for further understanding how external risk, clients' organizational behavior, and project definition in contract may lead to contractors' claims in international EPC projects, the relevant themes worthy of survey have been transferred into questions as below:

1) What is the status of external risks that cause contractors' claims?

2) What is the status of clients' organizational behaviors that cause contractors' claims?

3) What is the status of international EPC project definitions that cause contractors' claims?

4) What is the frequency of claims in international EPC projects?

5) What are the relationships among these themes?

\section{Empirical research methods}

\subsection{Triangulated approach for data collection}

As the triangulated approach (collectively using qualitative and quantitative methods) can help deeper understanding of a research proposition (Love et al. 2002), this study applied questionnaire, interview, and case study to collect data.

The questionnaire survey was selected as the method for collecting quantitative data. The researchers (Krosnick, Presser 2010; Srinivasan, Basu 1989; Martin 1978) indicate that the reliability of 5- and 7-point scales were almost identical. Sometimes 5-point scales can result in better quality data than 7-point regarding quality of measurement, since a higher point Likert scale makes it harder for respondents to distinguish definitions across the scales, and more time consuming to answer the questions (Revilla et al. 2013). Thus, a five-point Likert scale ranging from 1 to 5 was adopted in the questionnaire of this study.

The questionnaire was derived from the conceptual model development by reviewing relevant literature, and included two groups of questions. The first group of questions were to extract general information of respondents such as positions and working experience. The second group of questions were to capture the status of external risk, clients' organizational behavior, project definition in contract, and claim based on their experience in delivering EPC projects. The detailed five-point Likert scale measurements are as below:

1) External risk was measured by three indicators: natural hazards, sociopolitical risks, and economic risks, where $1=$ the least important, and $5=$ the most important;

2) Clients' organizational behavior was measured by three indicators: untimely payment, inefficient processing, and change orders, where $1=$ not very often, and 5 = very often;

3) Project definition in contract was measured by two indicators: unclear scope of works, and unclear technical specification, where $1=$ not very often, and $5=$ very often;
4) Claim was measured by two indicators: frequency of claims, and frequency of counterclaims, where $1=$ low and $5=$ high.

To avoid the low response rate of a postal survey (Akintoye, Macleod 1997), the questionnaire survey was fulfilled during seven field trips (one trip to the project site located in Ghana, and six trips to the headquarters of the experienced Chinese contractors). As Chinese contractors account for about $50 \%$ of market share in global hydropower industry (Wang et al. 2013; Shen 2012), a total of 109 questionnaires were collected from the contractors in delivery hydropower EPC projects. The sample distribution was: Pakistan (28), Fiji (11), Iran (6), Zambia (29), Equatorial Guinea (24), and Ghana (11). These countries were selected because of the following reasons: 1) Chinese contractors are active in Africa and Asia-Pacific regions (Chen, Orr 2009); 2) these countries are all developing countries, which have many similar features such as economic development level; 3) the selected hydropower projects in these countries are all located in valleys with adverse natural environment, facing with similar risks such as natural hazards (e.g. floods) and inconvenient transportation (Tang et al. 2013, 2016). Thus, the data collected from these countries can be collectively used to obtain general findings with a sounder base than data collected from one country.

After completion of questionnaire survey, semistructured interviews were conducted with 48 respondents who held senior positions such as CEO of companies, project manager, chief engineer and department head so as to get detailed information about claims in international EPC projects. The questions in the questionnaire were used as interview topics, and the respondents further explained their views on specific questions that they were interested in. The above methods collectively assisted the researchers in studying seven cases experienced by the respondents.

\subsection{Data analysis techniques}

The questionnaires were all collected for the sake of the fieldwork approaches used in this survey. By excluding two invalid questionnaires, 107 questionnaires were used for analysis. On average, the respondents have 12 years of work experience, with rich knowledge and skills in delivering international EPC hydropower projects. The collected data from the questionnaires was analyzed with the assistance of the Statistical Package for Social Science (SPSS 19.0) and the Analysis of Moment Structures (AMOS 17.0). The survey results were analyzed by estimation of the sample population mean and reliability test to know the status on the causes of claims. Structural equation modeling (SEM) is a causal modeling technique, which is ideally suitable for representing, estimating, and validating complex interactions among observed or latent variables (Jöreskog, Sörbom 1996). Although an ideal sample size of SEM is at least 200 or 20 cases per parameters (Kline 1998), the sample size-to-parameters 
Table 2. Survey results on causes of contractors' claims in international EPC projects

\begin{tabular}{|c|c|c|c|c|}
\hline Latent factors & Observed indicators & Mean & CFA factor loading & Cronbach's $\alpha$ \\
\hline \multirow[t]{3}{*}{ External risk } & Sociopolitical risks & 3.22 & $0.68^{* * *}$ & 0.681 \\
\hline & Natural hazards & 2.86 & $0.56^{* * *}$ & \\
\hline & Economic risks & 2.37 & $0.56^{* * *}$ & \\
\hline \multirow{3}{*}{$\begin{array}{l}\text { Clients' } \\
\text { organizational } \\
\text { behavior }\end{array}$} & Untimely payment & 3.38 & $0.69^{* * *}$ & 0.655 \\
\hline & Change orders & 3.34 & $0.52^{* * *}$ & \\
\hline & Inefficient processing & 2.86 & $0.38^{* * *}$ & \\
\hline \multirow{2}{*}{$\begin{array}{l}\text { Project definition } \\
\text { in contract }\end{array}$} & Unclear technical specification & 3.52 & $0.66^{* * *}$ & 0.764 \\
\hline & Unclear scope of works & 2.98 & $0.75^{* * *}$ & \\
\hline \multirow[t]{2}{*}{ Claim } & Frequency of claims & 3.41 & $0.95^{* * *}$ & 0.663 \\
\hline & Frequency of counterclaims & 2.37 & $0.55^{* * *}$ & \\
\hline Total & & & & 0.744 \\
\hline
\end{tabular}

Note: $* * *=$ correlation is significant at the 0.001 level (two-tailed)

ratio 10:1 is also recommended (Jackson 2003; Hair et al. 1998; Wolf et al. 2013). As there are 109 cases and 10 parameters in this research, which meet the hurdle of the sample size-to-parameters ratio, this study applied SEM to test the hypothesized relationships established in the conceptual model. Case studies were further used to validate and interpret the substantive meaning of the model.

\section{Survey results}

The survey results on the status of external risk, clients' organizational behavior, project definition in contract, and claim are shown in Table 2.

In order to validate the internal consistency, Cronbach alphas reliability testing was conducted by using the Statistical Package for Social Sciences (SPSS). The value of Cronbach's alphas between 0.6 and 0.7 can be considered as sufficient and the value greater than 0.7 is regarded as good (Sharma 1996). As shown in Table 2, Cronbach's alphas of all factors are greater than 0.6 , suggesting that the internal consistency reliability of the model is sufficient. The results in Table 2 reveal the different extents to which external risk, clients' organizational behavior, project definition in contract can cause claims. The quantifiable relationships among them will be explored through SEM analysis next.

\section{SEM analysis}

To reveal the underlying factor mechanism and test the appropriateness of the proposed grouping of causes of claims, exploratory factor analysis (EFA) was applied, as presented in Table 3.

The KMO value is 0.617 and the significance level of Bartlett's test of sphericity is 0.000 ( $p<0.01)$, indicating that the data were suitable for factor analysis. As listed in Table 3, three factors were extracted, namely external risk, clients' organizational behavior, project definition in contract, which cumulatively explain $70.12 \%$ of
Table 3. Exploratory factor analysis for causes of claims

\begin{tabular}{lccc}
\hline & \multicolumn{3}{c}{ Component } \\
\cline { 2 - 4 } & 1 & 2 & 3 \\
\hline Sociopolitical risks & $\mathbf{0 . 8 8 3}$ & 0.162 & -0.163 \\
Economic risks & $\mathbf{0 . 8 1 6}$ & 0.083 & 0.136 \\
Natural hazards & $\mathbf{0 . 7 2 2}$ & 0.379 & -0.013 \\
Untimely payment & 0.303 & $\mathbf{0 . 7 7 2}$ & -0.003 \\
Change orders & 0.069 & $\mathbf{0 . 7 3 5}$ & -0.075 \\
Inefficient processing & 0.159 & $\mathbf{0 . 7 2 8}$ & 0.196 \\
Unclear scope of works & -0.001 & -0.011 & $\mathbf{0 . 9 1}$ \\
Unclear technical & -0.015 & 0.078 & $\mathbf{0 . 8 6 9}$ \\
specification & & &
\end{tabular}

the total variance. The results verify the appropriateness of the grouping of causes of claims (see Fig. 1).

The validity of the model is examined by a twostep procedure comprising the confirmatory factor analysis (CFA) and the SEM phase (Jöreskog, Sörbom 1996). The confirmatory factor analysis was applied to test the validity and reliability of the measurement model, with the factor loadings presented in the fourth column of Table 2 and the model fit indicators presented in the second column of Table 4.

All CFA factor loadings (see Table 2) are above 0.5 at the significant level of $\mathrm{p}=0.001$, and model fit indicators (see Table 4) reach the hurdles, except TLI is at the acceptable borderline, demonstrating an acceptable fit between the measurement model and the data.

Convergent and discriminant validity are conducted to test the construct validity. Convergent validity, which is used to measure the homogeneity of latent constructs, is estimated by factor loadings. As reported in Table 2, factor loadings of all variables are statistically significant at $\mathrm{p}=0.001$ level, indicating that the convergent validity is satisfied (Anderson, Gerbing 1988). Discriminant 
Table 4. Overall Goodness-of-Fit measures of CFA and the final model

\begin{tabular}{lccll}
\hline \multicolumn{1}{c}{ GOF } & CFA & Final model & \multicolumn{1}{c}{ GOF range } & Threshold \\
\hline X2/DF & 2.00 & 1.92 & 0 or above & $1.00-3.00$ \\
GFI & 0.90 & 0.90 & 0 (no fit) to 1 (perfect fit) & 0.9 or above \\
TLI & 0.85 & 0.86 & 0 (no fit) to 1 (perfect fit) & 0.9 or above. \\
CFI & 0.90 & 0.90 & 0 (no fit) to 1 (perfect fit) & 0.9 or above \\
RMSEA & 0.098 & 0.093 & 0 (perfect fit) to 1 (no fit) & 0.1 or below \\
\hline
\end{tabular}

Note $:$ GOF $=$ goodness-of-fit indexes; $\mathrm{X}^{2} / \mathrm{DF}=$ chi square/degree of freedom; GFI = goodness-of-fit index;

TLI = Tucker-Lewis index; CFI = comparative fit index; and RMSEA = root-mean-square error of approximation.

validity, which measures the extent to which how different a construct is from other constructs, was estimated by comparing the square root of AVE for each construct and inter-construct correlations (Fornell, Larcker 1981). The discriminant validity assessment of latent constructs was performed, as shown in Table 5.

Table 5. Discriminant validity assessment of latent constructs

\begin{tabular}{lcccc}
\hline \multicolumn{1}{c}{ Latent constructs } & 1 & 2 & 3 & 4 \\
\hline $\begin{array}{l}\text { 1. External risk } \\
\text { 2. Clients' }\end{array}$ & $\mathbf{0 . 5 9 9}$ & & \\
organizational & $0.458^{* *}$ & $\mathbf{0 . 5 4 1}$ & \\
behavior & & & \\
$\begin{array}{l}\text { 3. Project } \\
\text { definition in }\end{array}$ & -0.029 & 0.067 & $\mathbf{0 . 7 0 7}$ \\
contract & & &
\end{tabular}

4. Claim $\quad 0.344^{* *} \quad 0.254^{* *} \quad 0.371^{* *} \quad \mathbf{0 . 7 8 3}$

Note: ${ }^{* *}=$ correlation is significant at the 0.01 level (twotailed).
As shown in Table 5, all the square roots of AVEs in diagonals were greater than inter-construct correlations in the off-diagonals, suggesting acceptable discriminant validity (Fornell, Larcker 1981).

The SEM was then applied to test the validity of the structural model (see Fig. 1). As some of the goodnessof-fit (GOF) indices of the initial model did not reach the recommended levels, model refinements were required to meet the recommended acceptance criteria. After model refinements based on both modification indices and solid theoretical support (Wong et al. 2009; Molenaar et al. 2000), the final SEM model was obtained (see Fig. 2). Table 4 reports the results of GOF indices of the final SEM model, with corresponding thresholds (Hair et al. 1998; Jashapara 2003; Chou, Bentler 1990; Brennan, Brannan 2005; Bollen, Long 1992; Browne, Cudeck 1993). As shown in Table 4, the values of GFI (0.90), CFI (0.90), RMSEA $(0.09$ at $\mathrm{p}<0.05)$ and ratio for $\mathrm{x} 2 / \mathrm{df}(1.92)$ are satisfactory, except the TLI (0.86) is at the acceptable

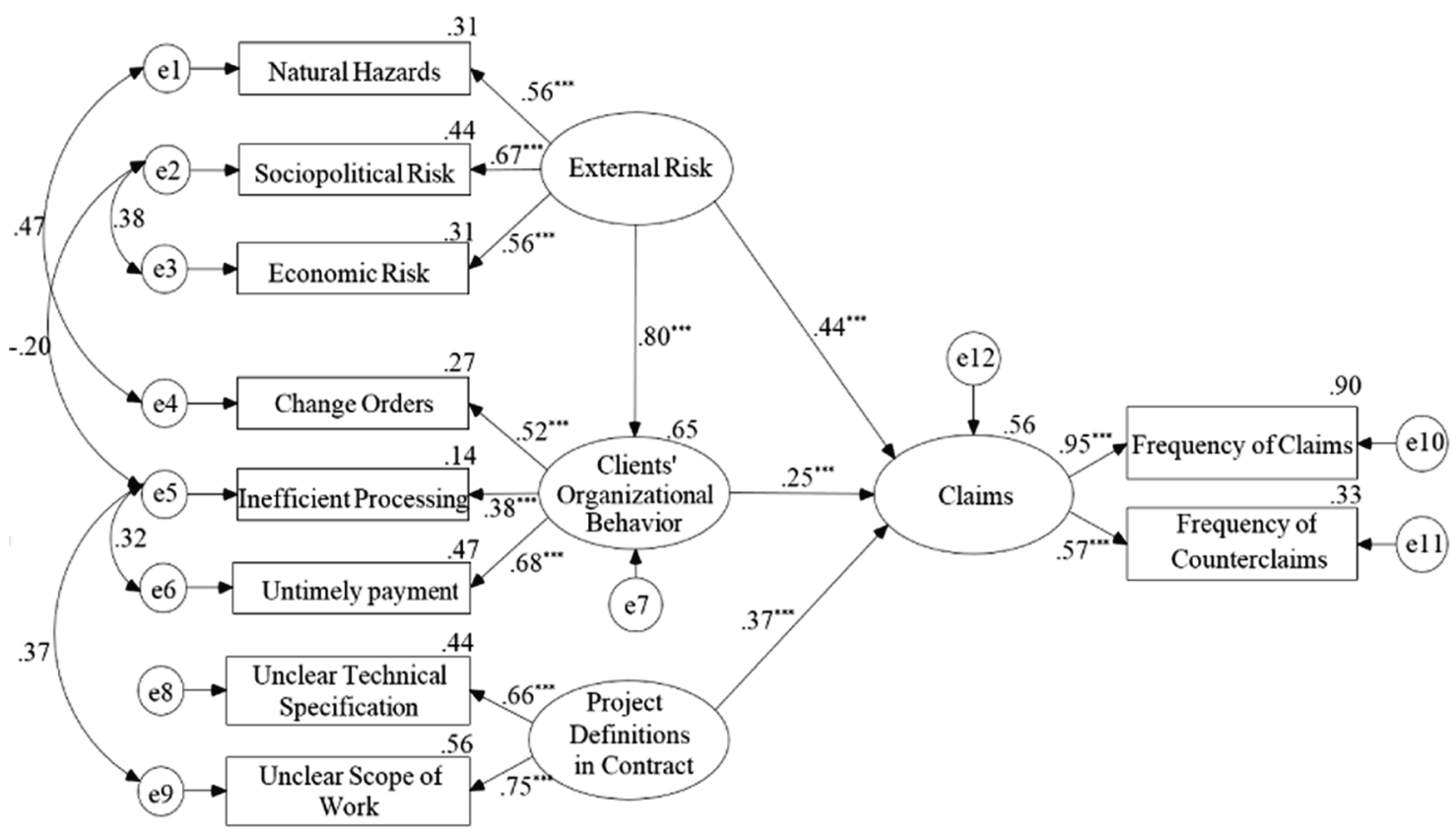

Note: ${ }^{* * *}=$ correlation is significant at the 0.001 level.

Fig. 2. Final model on causes of contractors' claims in EPC projects 
Table 6. International EPC project profiles

\begin{tabular}{lccccccc}
\hline \multicolumn{1}{c}{ Project } & $\mathrm{A}$ & $\mathrm{B}$ & $\mathrm{C}$ & $\mathrm{D}$ & $\mathrm{E}$ & $\mathrm{F}$ & $\mathrm{G}$ \\
\hline Location & Pakistan & Fiji & Pakistan & Iran & Zambia & $\begin{array}{c}\text { Equatorial } \\
\text { Guinea }\end{array}$ & $\begin{array}{c}\text { Ghana } \\
\text { Year started }\end{array}$ \\
\hline Contract duration(months) & 2007 & 2008 & 2003 & 2003 & 2008 & 2008 & 2008 \\
Actual duration(months) & 40 & 36 & 48 & 46 & 48 & 42 & 56 \\
Percentage of time overrun & 70 & 48 & 52 & 54 & 65 & 42 & 56 \\
Project contract price (US\$ million) & $75 \%$ & $33 \%$ & $8 \%$ & $17 \%$ & $26 \%$ & $0 \%$ & $0 \%$ \\
Actual payment to the contractor (US\$ million) & 112 & 131 & 66 & 143 & 290 & 257 & 597 \\
Percentage of cost overrun & $29 \%$ & $5 \%$ & $113 \%$ & $0 \%$ & $5 \%$ & $0 \%$ & $0 \%$ \\
\hline
\end{tabular}

borderline, indicating acceptable fit to the data in the final model.

As shown in Figure 2, external risk is the most influencing factor with the highest positive correlations of 0.44 , confirming that natural hazards, sociopolitical risks and economic risks are important causes of claims. Clients' organizational behavior is also correlated with claim with the correlation being 0.25 , supporting that untimely payment, inefficient processing, and change orders from clients have important influences on claim. Notably, external risk is strongly correlated with clients' organizational behavior with the high positive correlations of 0.8 , demonstrating that external risk have significant impact on clients' organizational behavior. The above relationships demonstrate a partial mediation of clients' organizational behavior between external risk and claim. This confirms that external risk can not only directly cause claim, but also exert influence on claim through affecting clients' organizational behavior.

The above SEM results have validated the relationships established in the conceptual model as seen in Figure 1. To interpret the substantive meaning of these relationships, the SEM model is further analyzed by conducting case studies below.

\section{Case studies}

\subsection{Project profiles}

With support of the data collected from interviews, and project documents review during field trips, seven international EPC hydropower projects were studied for further understanding the causes of claims. The project profiles are shown in Table 6.

The distribution of the selected cases is as: three in Asia, three in Africa, and one in Oceania, which is in line with the project development needs of these regions. These projects are all based on EPC contract form (FIDIC 1999). The outcomes of these projects (see Table 6) show that time and cost overruns can be significant in EPC projects, which are closely associated with contractors' claims. How external risk, client organizational behavior and project definition in contract lead to contractors' claims in these projects is explained below.

\subsection{Project A}

The claims in project A confirm that external risk can not only directly result in claims, but also exert influence on claims through affecting clients' organizational behavior, which can explain the paths presented in SEM (see Fig. 2) as below.

\section{1) Economic risks $\rightarrow$ Untimely payment $\rightarrow$ Claims}

In 2008, Pakistan's economy was affected by the global financial crisis, and encountered problems such as financial deficit and inflation. The unfavourable external events had a negative impact on the client's behavior. Because of financial problem, the client frequently delayed in a large amount payment. This led to the contractor's suspension of part of the works according to Sub-Clause 16.1 on Contractor's Entitlement to Suspend Work, and submission of claims for extension of time and cost compensation in accordance with Sub-Clause 14.8 on Delayed Payment (FIDIC 1999). The two parties reached agreement on the extension of time of 530 days, but left the claim for cost compensation being unsettled. After obtaining international aid of US\$ 38 million, the client managed to solve the payment problem. Finally, the contractor received additional payment of US\$ 7.22 million to cover the incurred costs caused by the delay; the contractor also obtained the interest of the delayed payment with amount of US\$ 4.55 million. In this case, the adverse economic condition reduced the client's affordability and affected its organizational behaviors (e.g. untimely payment), ultimately resulting in claims.

\section{2) Economic risks $\rightarrow$ Claims}

The contractor was also entitled to claim for the increased costs resulting from the price escalations of labor force and six main materials (including cement, reinforcement, section steel, coal ash, oil, and explosives). Eventually, the client approved US\$ 14.49 million to cover the costs from price increasing, accounting for $16.6 \%$ of total contract value. Besides, a rainstorm, which was the most serious in the past five decades, occurred at the end of July in 2010. The switch station that was about to complete was destroyed by floods, landslides and mudflows caused by the extreme weather. In dealing with this 
event, the contractor had presented claims to relevant insurance company and the client, respectively. First, the contractor timely sent a letter to the insurance company for conducting site survey, and then submitted a claim report for compensation. After negotiations, the contractor obtained $\$ 3.36$ million paid by the insurance company. Second, the contractor presented a plan including the schedule for reconstruction of the switching station, which was approved by the client. The above claims for the price escalations and the rainstorm can interpret how the economic risk and natural hazard have direct influences on claims, as shown in Figure 2.

\subsection{Project $B$}

The claims in project B confirm that external risk and clients' organizational behavior can have direct influences on claims, as presented in Figure 2. The interpretations of the findings of SEM are as below.

\section{1) Natural hazards $\rightarrow$ Claims}

Project B located in Fiji, an island country in Pacific Ocean region, where typhoon is one of the natural hazards that may affect project delivery. On December 14th 2009 , the project site suffered heavy loss from the typhoon MICK. After receiving early warnings of typhoons from the national weather station on 12th March 2010 and 28th November 2010, the contractor transferred the construction materials and equipment to safety places to avoid the impacts of the coming typhoons, which interrupted the normal construction processes. In 5 December 2010 , the flood caused by a heavy rain damaged the water diversion tunnel and affected the construction of the dam. The contractor submitted relevant claim, and obtained the client's approval on the extensions of time.

\section{2) Socio-political risks $\rightarrow$ Claims}

One event was that the project delivery processes were frequently disturbed by the local residents due to the dispute between the client and local communities. The client approved the contractor's claim on time extension without any compensation. Another event was that the explosives were scheduled to purchase from New Zealand for the project. However, the tense relationship between the Fijian and New Zealand governments led to delays in the delivery of explosives from New Zealand to the construction site. The contractor's time extension claim resulted from the political risk was approved by the client.

\section{3) Inefficacy processing $\rightarrow$ Claims}

When the first shipment of equipment arrived in the port, the client did not timely pay duties, leading to delay in customs clearance. Besides, the client did not give feedback on the basic design report submitted by the contractor within specified period. The client agreed with the contractor's requirements on time extension for these two claims.

\section{4) Change orders $\rightarrow$ Claims}

The change orders in this project included: changing the planning of the switch station, recovering the road to switch station, adding protective layer of pressure pipes, and constructing $1.4 \mathrm{~km}$ concrete road to the power plant. Totally, the contractor obtained the compensation payment of US\$ 1.1 million.

\subsection{Project C}

The claims in project $\mathrm{C}$ validate the findings of SEM that external risk, inefficient processing of the client, and unclear project definition in contract can have direct effects on claims (see Fig. 2), which are explained as below.

1) External risks (natural hazards, economic risks, and sociopolitical risks) $\rightarrow$ Claims

On 8 October 2005, an earthquake struck with a magnitude of 7.6, and the epicentre was $95 \mathrm{~km}$ away from the project site, causing both casualties and property losses of the contractor. Moreover, the earthquake damaged the roads that linked the project site with outside, and had affected the transportation of materials for about six months. The contractor submitted claims to the insurance company asking for compensation for the additional costs resulting from the earthquake and the flood. By providing sufficient supporting documents, the contractor successfully obtained cost compensation from the insurance company. In addition, the contractor asked for extension of time and was approved by the client.

In 2007, price of materials and fuels rose sharply. In accordance with the contract, the contractor was entitled to obtain compensation due to the inflation. After rounds of negotiations on the use of price adjustment formulas, the claim for price escalation was settled with a compensation amount of US\$ 18 million.

On 8 November 2007, the local government launched a military campaign against the terrorism organization in the project located area. The client ordered the contractor to evacuate from the construction site to the safety place for half a year. The two parties reached an agreement on compensation of additional cost and time.

\section{2) Insufficient processing of the client $\rightarrow$ Claims}

In accordance with the contract, the client should provide four access routes to the site before the commencement of the project. However, the client was unable to deliver them in time. Then, the client ordered the contractor to design and construct these four roads by signing an amendment to the contract. The client approved the extension of four months and the relevant compensation payment to the contractor.

\section{3) Unclear project definition in the contact $\rightarrow$ Claims}

The client promised to supply the electricity with capacity of 3.0 MW from the regional power grid. However, the contractor also agreed in the bidding document to provide electricity generators with capacity of $2.54 \mathrm{MW}$. 
Both parties did not specify their respective price of electricity. In practice, the client was unable to provide electricity, and the actual capacity of electricity generators installed by the contractor was $3.72 \mathrm{MW}$ to meet the energy need of construction. As the price of electricity generated by the contractor was much higher than the price of electricity from power grid, the contractor required cost compensation. Disputes existed over who should provide the electricity and who should bear the extra cost from the price difference. The negotiations lasted 6 years till the completion of the project. Finally, the two parties reached an agreement that the client should compensate the extra cost within the capacity of $3.0 \mathrm{MW}$, and the contractor should bear the actual cost exceeding the capacity of 3.0 MW. The contractor received US\$ 2.63 million in compensation of using electricity.

After the commencement of the project, it was found that the client's conceptual design was insufficient, leading to unclear scope of works for the contractor to proceed. The contractor had to conduct additional geological exploration to decide feasible design options, which caused delay and extra costs. The client agreed with the contractor's requirements on time extension and extra costs.

\subsection{Projects $D, E$, and $F$}

The claims in Projects D, E, and F confirm that sociopolitical risks and insufficient processing of the client can directly result in claims, and also support that clients' organizational behaviour can play a mediation role between economic risks and claims, as shown in Figure 2. The explanations of the implications of SEM model are as below.

\section{1) Sociopolitical risks $\rightarrow$ Claims}

In project $\mathrm{D}$, the inconsistent judgments of Bureau of labor have provoked the local workers' strike, which significantly influenced the execution of the project. The client sought the help of the police to stop the strike, and agreed on the time extension requirement of the contractor.

\section{2) Economic risks $\rightarrow$ Untimely payment $\rightarrow$ Claims}

In project $\mathrm{E}$, the client was influenced by the financial crisis of 2008 and encountered the financing difficulty, leading to untimely payments, which is similar to project A. The contractor helped the client to successfully obtain export credits from the Export-Import Bank of China, which was largely improved the client's financial situation in supporting the development of the project. The client awarded an extension of time of 17 months and the late-payment interest of US\$ 2.4 million.

\section{3) Insufficient processing of the client $\rightarrow$ Claims}

In the case of project $\mathrm{E}$, the customs duties and value-added tax in the import of equipment should be exempted in accordance with the local laws. However, the client did not help the contractor to obtain permission for duty-free importation in a timely manner. The contractor received compensation to cover the additional payment for the taxes.

At the early stage in delivering project $\mathrm{F}$, the client did not timely provide the access routes to the site, which considerably affected the transport of materials and equipment for construction. The contractor submitted claims for delay and additional costs caused by the client's inefficiency in delivery of the access roads. Due to the tight cash flow situation, the client only approved time extension but refused the contractor's requirement for extra costs.

The cases above have validated that the relationships established in the SEM model (see Fig. 2). External risk, clients' organizational behavior, and project definition in contract can independently result in contractors' claims in EPC projects. Besides, the case studies have confirmed how the external risks, associated with client's organizational behaviors, result in claims. For example, in project $\mathrm{A}$ and project $\mathrm{E}$, the economic risks significantly influenced the clients' cash flow, which resulted in untimely payment and contractors' corresponding claims.

\section{Discussion}

According to the features of international EPC projects, this research refines the various causes of claims from previous studies into three factors that may have impacts on contractors' claims. On the basis of this, the model on causes of contractors' claims in EPC projects has been developed and tested, revealing the interrelationships among external risk, clients' organizational behavior, project definition in contract, and claim. The results have confirmed and advanced the findings in the previous literatures, which have significantly theoretical and practical implications.

The causes of claims in EPC projects may be different from traditional DBB projects, due to EPC contractors bearing more risks as a single entity responsible for design, procurement, and construction (Galloway 2009; Scott, Harris 2004). This is supported by the results of SEM, in which the external risk has the highest correlations with claim (standard coefficient $=0.44$ ) among the three factors in the model (see Fig. 2). Interviews with project managers during fieldtrips also confirm that international EPC projects have higher level of external risk than in the domestic market due to complex natural, sociopolitical, and economic conditions in the international environment. Specifically, hydropower projects are normally located in valley with hazardous environment, leading to circumstances where hydropower project construction sites are likely to suffer from natural hazards such as extreme weather, floods, landslides, mudflows and earthquakes. These natural hazards can cause delays and losses, and accordingly, contractors can claim for extension of time and compensation of additional cost. Comparatively, claims in traditional DBB projects in domestic market are more related to design errors and 
omissions, unforeseen site conditions, material and equipment quality problems (Pishdad-Bozorgi, Garza 2012; Tang et al. 2007, 2013). This finding suggests that EPC project participants should allocate necessary resources to timely extract and interpret information from international environment, for properly mitigating and responding to external risks.

The propositions on market uncertainty, behavior conflict and opportunism (Williamson 1975; Mitropoulos, Howell 2001; Cheung, Pang 2013) are confirmed by the outcomes of SEM, in which clients' organizational behavior is statistically significant correlated with external risk (standard coefficient $=0.8$ ) and claim (standard coefficient $=0.25$ ). These results demonstrate that organizational behaviour, closely associated with external risk, is an important cause of claims, implying that participants need to cooperatively deal with project risks. For example, the late-payment problem in project E was solved by the contractor's helping the client for financing. This suggests that sometimes, adopting partnering strategy to jointly mitigate the impacts of external risks is more effective to deal with the contractual problems and reduce conflicts than litigation.

The findings of this study also support that clarity of project scope/requirements is a key influencing factor in EPC projects (Xia et al. 2013). As shown in Figure 2, the statistically significant correlation between project definition in contract and claim (standard coefficient $=0.37$ ) indicates that unclear scope of works and unclear technical specifications play important roles in affecting claim. This can also be explained by case studies. For example, cost overrun (113\%) in project $\mathrm{C}$ was largely attributed to the unclear definition of project scope and technical specification (see Table 6). Thus, it is necessary to clearly define project scope/technical specification in EPC contracts. Besides, as many uncertainties will still be left to deal with in processes of EPC project delivery, building links among participants for efficiently clarifying project issues is indispensable to minimize claims and disputes.

\section{Conclusions}

Management of claims is one of the biggest challenges in current changing international construction industry (Kululanga et al. 2001). Existing studies have identified wide-range causes of claims, which are related to industrial, financial, social, political, organizational behavior, contractual, environmental, and project-related factors (Cheung, Pang 2013; Fawzy, El-adaway 2012; Love et al. 2011; Abd El-Razek et al. 2008; Sambasivan, Soon 2007; Yates, Epstein 2006; Harmon 2003; Odeh, Battaineh 2002). However, little research has systematically addressed and quantified the relationships among these factors and their association with claims in EPC project delivery approach, which is increasing favored in international markets. Thus, there is a clear need to study how these factors interactively influence contractors' claims in international EPC projects.
On the perspective of contractors in international EPC projects, the causes of claim can be refined as: external risk (sociopolitical risks, economic risks, and natural hazards), clients' organizational behavior (untimely payment, change orders, and inefficient processing), and project definition in contract (unclear scope of works, and unclear technical specification). This rationale has been modeled and empirically tested with industry survey, SEM and case studies. The findings of this study demonstrate that external risk, clients' organizational behavior, and project definition in contract can have direct influences on claim respectively. Besides, clients' organizational behavior acts as a partial mediation between external risk and claim, confirming that external risk can also exert influence on claim through affecting clients' organizational behavior. Seven case studies have further validated and interpreted the substantive meaning of the above relationships, e.g., the financial crisis can lead to the client's untimely payments, and the flood can cause change orders for reconstruction.

The above findings suggest broad practical strategies coping with contractors' claims in international EPC projects: 1) timely collecting information from complex environment to properly prevent and respond to external risks; 2) promoting partnering among participants on the basis of equitable risk allocation, trust, and open communication, to reduce uncertainties in project implementation and conflicts from opportunism behaviors; 3) clearly defining project scope of works and technical specification, to decrease claims and disputes originating from ambiguous EPC contracting provisions.

The results of this study contribute to the body of knowledge in both theory and practice. First, this research builds interdisciplinary linkages among knowledge areas of contracting, risk management, organizational behavior, and international EPC project delivery, which fill the gap in the body of literature to examine the interrelationships among these themes as a whole (Awwad et al. 2016; Mitropoulos, Howell 2001). Second, this study has established and tested a systematic model that theoretically demonstrates contractors' claims could derive from complex external environment, clients' behaviors, and project-specific natures on a broad view. The findings quantitatively support the propositions on market uncertainty, behavior conflict and opportunism (Williamson 1975; Cheung, Pang 2013), and illustrate that external risk can affect organizational behavior, thereby result in contractual problems. Third, the survey results and the case studies provide sound empirical evidences for learning how contractors' claims have actually occurred in international EPC projects. The findings confirm the different features of risks in delivering EPC projects and traditional DBB projects (Galloway 2009; Scott, Harris 2004), indicating that contractors need to take account of a wider range of risks rather than mainly focusing on project-specific technical issues. Fourth, understanding the above relationships and the relevant management status can help 
participants to find broad practical strategies on an informed basis, in appropriately dealing with claim-related issues and preventing the recurrence of the contractual problems.

There are several limitations of this study. First, the data in this research were collected from the Chinese contractors in hydropower industry. Second, the sample size is relatively small, compared to the large number of international EPC projects. However, as the insights in this research are derived from worldwide experience via literature, it appears that the findings of this study can be transferable to different industries.

In the light of the outcomes and limitations of this study, we propose the following future research directions: 1) validating the model by collecting data in different industries from different perspectives of project participants such as clients, designers, and consultants; 2) studying the causes of claims in different countries by considering their specific risks; 3) exploring how project participants can correctly perceive changing external environment and to properly dealing with sociopolitical risks, economic risks, and natural hazards; 4) studying participants' cooperative behaviors to understand the way for reducing opportunism and reaching appropriate tradeoff with win-win value; 5) investigating how to clearly define EPC project scope and technical specification, and to establish links among participants for efficiently clarifying the project issues during project implementation, thereby minimizing claims and disputes.

\section{Acknowledgements}

The work described in this paper was supported by a grant from/ Many thanks are given to the National Natural Science Foundation of China (Grant Nos. 51379104, 51579135,51079070, 50539130 and 70671058), State Key Laboratory of Hydroscience and Engineering (Grant Nos. 2013-KY-5, 2015-KY-5, 2009-ZY-7), and Major Science and Technology Research Project of Power China (Grant Nos. DJ-ZDZX-2015-01-02, DJ-ZDZX-2015-01-07). The authors thank Sinohydro and the respondents for the valuable information they provided during the survey.

\section{References}

Abd El-Razek, M. E.; Bassioni, H. A.; Mobarak, A. M. 2008. Causes of delay in building construction projects in Egypt, Journal of Construction Engineering and Management 134(11): 831-841.

https://doi.org/10.1061/(ASCE)0733-9364(2008)134:11(831)

Abdul-Malak, M. A. U.; El-Saadi, M. M.; Abou-Zeid, M. G. 2002. Process model for administrating construction claims, Journal of Management and Engineering 18(2): 84-94. https://doi.org/10.1061/(ASCE)0742-597X(2002)18:2(84)

Akintoye, A. S.; MacLeod, M. J. 1997. Risk analysis and management in construction, International Journal of Project Management 15(1): 31-38.

https://doi.org/10.1016/S0263-7863(96)00035-X

Anderson, J.; Gerbing, D. 1988. Structural equation modeling in practice: a review and recommended two-step approach, Psychological Bulletin 103(3): 411-423.

https://doi.org/10.1037/0033-2909.103.3.411
Assaf, S. A.; Al-Hejji, S. 2006. Causes of delay in large construction projects, International Journal of Project Management 24(4): 349-357.

https://doi.org/10.1016/j.ijproman.2005.11.010

Awwad, R.; Barakat, B.; Menassa, C. 2016. Understanding dispute resolution in the Middle East Region from perspectives of different stakeholders, Journal of Management in Engineering 32(6), 05016019. https://doi.org/10.1061/(ASCE)ME.1943-5479.0000465

Bollen, K. A.; Long, J. S. 1992. Tests for structural equation models: Introduction, Sociological Methods \& Research 21(2): 123-131. https://doi.org/10.1177/0049124192021002001

Brennan, E. M.; Brannan, A. M. 2005. Participation in the paid labor force by caregivers of children with emotional and behavioral disorders, Journal of Emotional Behavioral Disorders 13(4): 237-246. https://doi.org/10.1177/10634266050130040501

Browne, M. W.; Cudeck, R. 1993. Alternative ways of assessing model fit, in K. A. Bollen and J. S. Long (Eds). Testing structural equation models. Sage Publications, Newberry Park, California, 445-455.

Chan, A. P.; Yeung, J. F.; Yu, C. C.; Wang, S. Q.; Ke, Y. 2010. Empirical study of risk assessment and allocation of public-private partnership projects in China, Journal of Management and Engineering 27(3): 136-148. https://doi.org/10.1061/(ASCE)ME.1943-5479.0000049

Chan, E.; Chan, A.; Yu, A. 2005. Design management in design and build projects: the new role of the contractor, in Construction Research Congress 2005, 1-11. https://doi.org/10.1061/40754(183)81

Chan, E. H.; Tse, R. Y. 2003. Cultural considerations in international construction contracts, Journal of Construction Engineering and Management 129(4): 375-381.

https://doi.org/10.1061/(ASCE)0733-9364(2003)129:4(375)

Chau, K. W. 2007. Application of a PSO-based neural network in analysis of outcomes of construction claims, Automation in Construction 16(5): 642-646. https://doi.org/10.1016/j.autcon.2006.11.008

Chen, C.; Orr, R. J. 2009. Chinese contractors in Africa: home government support, coordination mechanisms, and market entry strategies, Journal of Construction Engineering and Management 135(11): 1201-1210. https://doi.org/10.1061/(ASCE)CO.1943-7862.0000082

Chester, M.; Hendrickson, C. 2005. Cost impacts, scheduling impacts, and the claims process during construction, Journal of Construction Engineering and Management 131(1): 102-107. https://doi.org/10.1061/(ASCE)07339364(2005)131:1(102)

Cheung, S. O.; Pang, K. H. Y. 2013. Anatomy of construction disputes, Journal of Construction Engineering and Management 139(1): 15-23. https://doi.org/10.1061/ (ASCE)CO.1943-7862.0000532

Chou, C. P.; Bentler, P. M. 1990. Model modification in covariance structure modeling: a comparison among likelihood ratio, Lagrange multiplier, and Wald tests, Multivariate Behavioral Research 25(1): 115-136. https://doi.org/10.1207/s15327906mbr2501 13

Daft, R. L. 2010. Organization theory and desigñ. South-Western Cengage Learning, Mason, $\mathrm{OH}$.

El-adaway, I.; Kandil, A. 2009. Contractors' claims insurance: a risk retention approach, Journal of Construction Engineering and Management 135(9): 819-825. https://doi.org/10.1061/(ASCE)CO.1943-7862.0000033

El-adaway, I.; Kandil, A. 2010. Construction risks: single versus portfolio insurance, Journal of Management and Engineering 26(1): 2-8. https://doi.org/10.1061/(ASCE)0742-597X(2010)26:1(2) 
Fawzy, S. El-adaway, I. 2012. Contract administration guidelines for managing conflicts, claims, and disputes under World Bank-funded projects, Journal of Legal Affairs and Dispute Resolution in Engineering and Construction 4(4): 101-110. https://doi.org/10.1061/(ASCE)LA.1943-4170.0000091

Fédération lnternationale Des lngénieurs Conseils (FIDIC). 1999. Conditions of contract for EPC-Turnkey projects. Lausanne.

Fornell, C.; Larcker, D. F. 1981. Evaluating structural equation models with unobservable variables and measurement error, Journal of Marketing Research 18(1): 39-50. https://doi.org/10.2307/3151312

Galloway, P. 2009. Design-build/EPC contractor's heightened risk - Changes in a changing World, Journal of Legal Affairs and Dispute Resolution in Engineering and Construction 1(1): 7-15. https://doi.org/10.1061/ (ASCE)1943-4162(2009)1:1(7)

Gunhan, S.; Arditi, D. 2005. Factors affecting international construction, Journal of Construction Engineering and Management 131(3): 273-282. https://doi.org/10.1061/ (ASCE)0733-9364(2005)131:3(273)

Guo, Q.; Xu, Z. P.; Zhang, G. F.; Tu, T. T. 2010. Comparative analysis between the EPC contract mode and the traditional mode based on the transaction cost theory, in 2010 IEEE $17^{\text {th }}$ International Conference on Industrial Engineering and Engineering Management, 2010, 191-195.

Hair, J. F.; Anderson, R. E.; Tatham, R. L.; Black, W. C. 1998. Multivariate data analysis. $5^{\text {th }}$ ed. Prentice-Hall, Upper Saddle River, N. J.

Hale, D.; Shrestha, P.; Gibson, G. Jr.; Migliaccio, G. 2009. Empirical comparison of design/build and design/bid/ build project delivery methods, Journal of Construction Engineering and Management 135(7): 579-587. https://doi.org/10.1061/(ASCE)CO.1943-7862.0000017

Hanna, A. S. 2007. Risk allocation and increased claims in the construction industry, Journal of Professional Issues in Engineering Education and Practice 133(1): 43-44. https://doi.org/10.1061/(ASCE)1052-3928(2007)133:1(43)

Harmon, K. M. J. 2003. Effectiveness of dispute review boards, Journal of Construction Engineering and Management 129(6): 674-679. https://doi.org/10.1061/(ASCE)07339364(2003)129:6(674)

Ho, S. P.; Liu, L. Y. 2004. Analytical model for analyzing construction claims and opportunistic bidding, Journal of Construction Engineering and Management 130(1): 94-104. https://doi.org/10.1061/(ASCE)07339364(2004)130:1(94)

Iyer, K. C.; Sagheer, M. 2010. Hierarchical structuring of PPP risks using interpretative structural modelling, Journal of Construction Engineering and Management 136(2): 151-159. https://doi.org/10.1061/(ASCE)CO.19437862.0000127

Jackson, D. L. 2003. Revisiting sample size and number of parameter estimates: Some support for the N: q hypothesis, Structural Equation Modeling 10(1): 128-141. https://doi.org/10.1207/S15328007SEM1001_6

Jashapara, A. 2003. Cognition, culture and competition: An empirical test of the learning organization, The Learning Organisation 10(1): 31-50. https://doi.org/10.1108/09696470310457487

Jöreskog, K. G.; Sörbom, D. 1996. LISREL 8 user's reference guide. Scientific Software. Chicago.

Kline, R. B. 1998. Principles and practice of structural equation modeling. New York: Guilford publications.

Krosnick, J. A.; Presser, S. 2010. Question and questionnaire design, in J. D. Wright, P. V. Marsden (Eds). Handbook of survey research. $2^{\text {nd }}$ ed. San Diego, CA: Elsevier, 263-314.

Kululanga, G.; Kuotcha, W.; McCaffer, R.; Edum-Fotwe, F. 2001. Construction contractors' claim process framework,
Journal of Construction Engineering and Management 127(4): 309-314. https://doi.org/10.1061/(ASCE)07339364(2001)127:4(309)

LaBarre, P. S.; El-adaway, I. H. 2013. Project benchmarking: Tool for mitigating conflicts, claims, and disputes through improved performance, Journal of Legal Affairs and Dispute Resolution in Engineering and Construction 6(1).

Levin, P. 1998. Construction contracts, claims, and disputes. Reston, VA: ASCE.

Love, P. E.; Edwards, D. J.; Irani, Z.; Goh, Y. M. 2011. Dynamics of rework in complex offshore hydrocarbon projects, Journal of Construction Engineering and Management 137(12): 1060-1070. https://doi.org/10.1061/(ASCE)CO.1943-7862.0000377

Love, P. E. D.; Holt, G. D.; Li, H. 2002. Triangulation in construction management research, Engineering, Construction and Architectural Management 9: 294-303. https://doi.org/10.1108/eb021224

Mahamid, I.; Bruland, A.; Dmaidi, N. 2012. Causes of delay in road construction projects, Journal of Management and Engineering 28(3): 300-310. https://doi.org/10.1061/(ASCE)ME.1943-5479.0000096

Martin, W. S. 1978. Effects of scaling on the correlation coefficient: Additional considerations, Journal of Marketing Research 15: 304-308. https://doi.org/10.2307/3151268

Mitropoulos, P.; Howell, G. 2001. Model for understanding, preventing, and resolving project disputes, Journal of Construction Engineering and Management 127(3): 223-231. https://doi.org/10.1061/(ASCE)07339364(2001)127:3(223)

Mohamed, K. A.; Khoury, S. S.; Hafez, S. M. 2011. Contractor's decision for bid profit reduction within opportunistic bidding behavior of claims recovery, International Journal of Project Management 29(1): 93-107. https://doi.org/10.1016/j.ijproman.2009.12.003

Molenaar, K.; Washington, S.; Diekmann, J. 2000. Structural equation model of construction contract dispute potential, Journal of Construction Engineering and Management 126(4): 268-277. https://doi.org/10.1061/(ASCE)07339364(2000)126:4(268)

Odeh, A. M.; Battaineh, H. T. 2002. Causes of construction delay: traditional contracts, International Journal of Project Management 20(1): 67-73. https://doi.org/10.1016/S02637863(00)00037-5

Orabi, W.; El-Rayes, K.; Senouci, A. B.; Al-Derham, H. 2009. Optimizing postdisaster reconstruction planning for damaged transportation networks, Journal of Construction Engineering and Management 135(10): 1039-1048. https://doi.org/10.1061/(ASCE)CO.1943-7862.0000070

Öztaş, A.; Ökmen, Ö. 2004. Risk analysis in fixed-price design-build construction projects, Building and Environment 39(2): 229-237. https://doi.org/10.1016/j.buildenv.2003.08.018

Pishdad-Bozorgi, P.; Garza, J. M. 2012. Comparative analysis of design-bid-build and design-build from the standpoint of claims, in Construction Research Congress 2012 - Construction Challenges in a Flat World, 2012, 21-30.

Ren, Z.; Anumba, C.; Ugwu, O. 2001. Construction claims management: towards an agent-based approach, Engineering Construction and Architectural Management 8(3): 185-197. https://doi.org/10.1108/eb021181

Revilla, M. A.; Saris, W. E.; Krosnick, J. A. 2013. Choosing the number of categories in agree-disagree scales, Sociological Methods \& Research 43(1), 0049124113509605. https://doi.org/10.1177/0049124113509605

Rosenfeld, Y. 2014. Root-cause analysis of constructioncost overruns, Journal of Construction Engineering and Management 140(1), 04013039. https://doi.org/10.1061/ (ASCE)CO.1943-7862.0000789 
Sambasivan, M.; Soon, Y. W. 2007. Causes and effects of delays in Malaysian construction industry, International Journal of Project Management 25(5): 517-526. https://doi.org/10.1016/j.ijproman.2006.11.007

Scott, S.; Harris, R. A. 2004. United Kingdom construction claims: Views of professionals, Journal of Construction Engineering and Management 130(5): 734-741.

https://doi.org/10.1061/(ASCE)0733-9364(2004)130:5(734)

Semple, C.; Hartman, F. T.; Jergeas, G. 1994. Construction claims and disputes: causes and cost/time overruns, Journal of Construction Engineering and Management 120(4): 785-795. https://doi.org/10.1061/(ASCE)0733-9364(1994)120:4(785)

Sharma, S. 1996. Applied multivariate techniques. New York: Wiley.

Shen, L. 2012. What makes China's investment successful in Africa: the entrepreneurial spirit and behavior of Chinese enterprises in transitional times, Journal of Developmental Entrepreneurship 17(4), 1250025. https://doi.org/10.1142/S1084946712500252

Srinivasan, V.; Basu, A. K. 1989. The metric quality of ordered categorical data, Marketing Science 8(3): 205-230. https://doi.org/10.1287/mksc.8.3.205

Tang, W.; Shen, W.; Zhen, L.; Wang, S.; Duffield. C. F.; Wei, Y.; Hui, F. K. P. 2016. Holistic hydropower scheme for China, Nature 532. https://doi.org/10.1038/532037d

Tang, W.; Qiang, M.; Duffield, C. F.; Young, D. M.; Lu, Y. 2007. Risk management in the Chinese construction industry, Journal of Construction Engineering and Management 133(12): 944-956. https://doi.org/10.1061/(ASCE)07339364(2007)133:12(944)

Tang, W.; Qiang, M.; Duffield, C. F.; Young, D. M.; Lu, Y. 2009. Enhancing total quality management by partnering in construction, Journal of Professional Issues in Engineering Education and Practice 135(4): 129-141.

https://doi.org/10.1061/(ASCE)1052-3928(2009)135:4(129)

Tang, W.; Li, Z.; Qiang, M.; Wang, S.; Lu, Y. 2013. Risk management of hydropower development in China, Energy 60: 316-324. https://doi.org/10.1016/j.energy.2013.08.034
Vidogah, W.; Ndekugri, I. 1998. Improving the management of claims on construction contracts: consultant's perspective, Construction Management and Economics 16(3): 363-372. https://doi.org/10.1080/014461998372385

Wang, S.; Tang, W.; Li, Y. 2013. Relationship between owners' capabilities and project performance on development of hydropower projects in China, Journal of Construction Engineering and Management 139(9): 1168-1178. https://doi.org/10.1061/(ASCE)CO.1943-7862.0000694

Williamson, O. E. 1975. Markets and hierarchies: analysis and antitrust implications. New York: The Free Press.

Williamson, O. E. 1979. Transaction cost economics: The governance of contractual relations, The Journal of Law \& Economics 22(2): 233-261. https://doi.org/10.1086/466942

Wolf, E. J.; Harrington, K. M.; Clark, S. L.; Miller, M. W. 2013. Sample size requirements for structural equation models an evaluation of power, bias, and solution propriety, $E d u$ cational and Psychological Measurement 73(6): 913-934. https://doi.org/10.1177/0013164413495237

Wong, P. S.; Cheung, S. O.; Fan, K. L. 2009. Examining the relationship between organizational learning styles and project performance, Journal of Construction Engineering and Management 135(6): 497-507.

https://doi.org/10.1061/(ASCE)CO.1943-7862.0000010

Xia, B.; Molenaar, K.; Chan, A.; Skitmore, M.; Zuo, J. 2013. Determining optimal proportion of design in design-build request for proposals, Journal of Construction Engineering and Management 139(6): 620-627.

https://doi.org/10.1061/(ASCE)CO.1943-7862.0000643

Yates, J. K.; Epstein, A. 2006. Avoiding and minimizing construction delay claim disputes in relational contracting, Journal of Professional Issues in Engineering Education and Practice 132(2): 168-179. https://doi.org/10.1061/ (ASCE)1052-3928(2006)132:2(168)

Zhi, H. 1995. Risk management for overseas construction projects, International Journal of Project Management 13(4): 231-237. https://doi.org/10.1016/0263-7863(95)00015-I

Wenxin SHEN. Ms. Wenxin Shen is now a PhD Candidate of Institute of Project Management and Construction Technology, Tsinghua University. Her research direction is on construction claim. She has participated in the whole processes of the study on international EPC hydropower project management.

Wenzhe TANG. Dr. Tang is an associate professor and the director of Institute of Project Management and Construction Technology, Tsinghua University. His research and teaching interests include partnering, organizational behavior, incentives, performance measurement, risk management, international project management, and hydropower development. Dr. Tang has successfully obtained research grants from National Natural Science Foundation of China, Education Ministry of China, Construction Ministry of China, State Key Laboratory of Hydroscience and Engineering. He has also been commissioned by top international contractors of China to provide consultancy services in both domestic and international project management. His research outcomes have been published in well-respected international journals such as Nature, Journal of Construction Engineering and Management-ASCE, Journal of Professional Issues in Engineering Education and Practice-ASCE, and Energy. He has obtained a number of awards since 1997, such as National Excellent Paper Award of Project Management Research Committee China (2013), Outstanding Performance Award of Tsinghua University (2013), and National Excellent Quality Management Award of the Construction Industry of China (2000). Dr. Tang holds a bachelor of engineering at Tsinghua University, a bachelor of management at Tianjin University, and a PhD in Engineering Project Management at the University of Melbourne. He also had been a consulting engineer of Guangxi Electric Power Design and Research Institute in China for 8 years, with experience on project planning, design, and construction management.

Wenyang YU. Mr. Wenyang Yu is a Master student of Institute of Project Management and Construction Technology, Tsinghua University. His research direction is on construction standard in international projects. He has participated in the study on international EPC hydropower project management.

Colin F. DUFFIELD. Prof. Duffield is the civil engineering discipline leader of Department of Infrastructure Engineering, The University of Melbourne. His research direction is on risk management.

Felix Kin Peng HUI. Dr. Felix Kin Peng Hui is a senior research fellow of Department of Infrastructure Engineering, The University of Melbourne. His research direction is on construction education.

Yongping WEI. Dr. Wei is an associate professor of School of Geography, Planning and Environmental Management, The University of Queensland. Her research direction is on water resource management.

Jun FANG. Mr. Jun Fang is the head of contracting department, Sinohydro Bureau 7 Co., LID. 